\title{
NILAI MULTIKULTURAL DALAM PEMBELAJARAN \\ PENDIDIKAN AGAMA ISLAM (PAI) DI SEKOLAH: Studi Terhadap Upaya Membina Karakter Siswa di SMKN 1 Gerung
}

\author{
Murzal \\ Universitas Islam Negeri Mataram \\ e-mail: murzalzal@yahoo.com
}

\begin{abstract}
Abstrak: Penelitian ini bertujuan untuk mengkaji tiga permasalahan utama, yaitu: nilai-nilai multikultural yang terdapat dalam pembelajaran PAI; proses penanaman nilai multikultural dalam pembelajaran PAI; metode pembinaan karakter melalui nilai multikulturalal dalam pembelajaran PAI. Penelitian dilakukan di SMKN 1 Gerung. Teknik analisis data yang digunakan pada penelitian ini meliputi pengumpulan data, reduksi data, penyajian data dan penarikan kesimpulan. Hasil penelitian ini menunjukkan bahwa nilai-nilai multikultural yang terdapat dalam buku mata pelajaran Pendidikan Agama Islam meliputi nilai toleransi, nilai kesamaan, nilai persatuan, nilai kekerabatan, dan nilai keadilan. Penanaman nilai-nilai multikultural dalam pembelajaran Pendidikan Agama Islam di SMKN 1 Gerung menggunakan dua metode yaitu metode keteladanan dan metode pembiasaan. Dampak penanaman nilai-nilai multikultural terhadap siswa yaitu tumbuhnya sikap saling toleran, menghormati, menerima pendapat orang lain, saling bekerjasama, tidak bermusuhan, dan tidak adanya konflik karena perbedaan budaya, suku, bahasa, adat istiadat, dan agama.
\end{abstract}

Kata Kunci: Nilai multikultural, pembelajaran, Pendidikan Agama Islam

Abstract: This study aims to examine three main problems, namely: multicultural values contained in Islamic Education (PAI) learning; the process of investing multicultural values in PAI learning; methods of character building through multicultural values in PAI learning. The study was conducted at SMK 1 Gerung, West Lombok. Data analysis techniques include data collection, data reduction, data display and conclusion verification. The findings show that multicultural values contained in PAI learning content include tolerance values, equality values, unity values, kinship values, and justice values. The planting of multicultural values in PAI learning at SMK 1 Gerung uses two methods, namely the exemplary method and the habituation method. The impact of planting multicultural values on students is the growth of mutual tolerance, respect, accepting the opinions of others, mutual cooperation, not hostile, and the absence of conflict due to differences in culture, ethnicity, language, customs, and religion.

Keywords: multicultural values, learning, Islamic education

DOI: https://doi.org/10.20414/jpk.v15i1.1103 


\section{PENDAHULUAN}

Dalam konteks Indonesia yang sarat dengan kemajemukan, pendidikan memiliki peran sangat strategis untuk dapat mengelola kemajemukan tersebut secara kreatif melalui penerapan pendidikan multikultural di sekolah-sekolah. Pendidikan merupakan salah satu media yang paling efektif untuk melahirkan generasi yang memiliki pandangan yang mampu menjadikan keragaman tersebut sabagai bagian yang harus diapresiasi secara konstruktif.

Pemahaman dan kesadaran terhadap realitas yang multikultural lewat jalur pendidikan dalam semua jenjang pendidikan tentu akan memiliki dampak yang konkret dalam kehidupan secara luas di masa mendatang. Untuk itu, pendidikan multikultural sangatlah penting dan urgen untuk diterapkan di sekolah-sekolah. Namun bila melihat kondisi bangsa yang mayoritas penduduknya adalah muslim, konsep pendidikan multikultural saja rasanya belumlah cukup untuk menjawab permasalahan-permasalahan di atas. Oleh karena itu diperlukan keterlibatan lembaga pendidikan Islam.

Namun, permasalahan yang mendasar dalam hal ini adalah sejauh mana orientasi pendidikan Islam dalam mengakomodir permasalahan-permasalahan tersebut. Untuk itu, diperlukan konsep pendidikan multikultural yang terintegrasi dengan pembelajaran pendidikan agama Islam (PAI) di sekolah. Pendidikan agama Islam adalah upaya sadar dan terencana dalam menyiapkan peserta didik untuk mengenal, memahami, menghayati, hingga mengimani, ajaran agama Islam, dibarengi dengan tuntunan untuk menghormati penganut agama lain dalam hubungannya dengan kerukunan antar umat beragama hingga terwujud kesatuan dan persatuan bangsa. ${ }^{1}$

Dari pengertian tersebut, dapat dikatakan bahwa pendidikan agama Islam pada hakikatnya sudah mengandung konsep pendidikan multikultural. Hal itu bisa dilihat dari konsep menghormati penganut agama lain sebagai wujud kesatuan dan persatuan bangsa. Selain itu banyak muatan nilai yang terkandung dalam pendidikan Islam yang sejalan dengan nilai multikultural, seperti nilai demokrasi, keadilan, toleransi, dan nilai yang lainnya. Namun demikian, diperlukan konsep yang jelas terkait dengan nilai-nilai multikultural yang terintegrasi dengan pembelajaran pendidikan agama Islam di sekolah.

Sekolah disebut sebagai komunitas multikultural karena memiliki kemampuan mengelola keragaman sehingga sekolah yang bersangkutan hidup dalam keragaman itu sendiri. Multikulturalisme merupakan suatu sistem kepercayaan dan perilaku yang mengakui dan menghargai kehadiran kelompok-kelompok yang beragam dalam organisasi atau masyarakat, memahami dan menilai perbedaan sosio-kultural mereka, dan mendorong serta mendukung mereka agar tetap memberi kontribusi berkesinambungan dalam suatu konteks kebudayaan inklusif yang memberdayakan semua dalam organisasi atau masyarakat. Jadi,

1 Abdul Majid dan Dian Andayani, Pendidikan Agama Islam Berbasis Kompetensi (Bandung: Remaja Rosdakarya, 2006), 130. 
multikulturalisme adalah menghargai orang dan pikiran-pikiran mereka, bukan menolak karena alasan berbeda dengan mayoritas. Esensi pendidikan multikultural adalah kemampuan untuk bekerja dengan orang lain dengan suatu cara yang melampaui seluruh beban dan membawa pada kesatuan dalam keragaman. ${ }^{2}$

Sekolah memiliki peranan penting dalam menanamkan nilai multikultural pada siswa semenjak dini. Bila sejak awal mereka telah memiliki nilai-nilai kebersamaan, toleran, cinta damai, dan menghargai perbedaan, maka nilai-nilai tersebut akan tercermin pada tingkah-laku mereka sehari-hari karena terbentuk pada karakter dan kepribadiannya. Bila hal tersebut dimiliki para generasi muda, maka kehidupan mendatang dapat diprediksi akan relatif damai dan penuh penghargaan antara sesama dapat terwujud.

Terkait dengan apa yang telah dijelaskan di atas, peneliti memilih SMKN 1 Gerung Lombok Barat sebagai objek penelitian dikarenakan pembelajarannya, khususnya pembelajaran pendidikan agama Islam, sudah mengintegrasikan nilai-nilai multicultural dalam membentuk karakter dan kepribadian siswanya. Di samping itu, nilai-nilai multikultural tersebut menjadi bagian dari pelaksanaan pendidikan karakter yang diterapkan di sekolah ini. Hal ini dapat dilihat dari materi, standar kompetensi dan kompetensi dasar, metode dan strategi pembelajaran maupun evaluasi yang dilaksanakan di SMKN 1 Gerung Lombok Barat.

Berdasarkan hasil observasi awal menunjukkan bahwa SMKN 1 Gerung merupakan sekolah favorit khususnya di kecamatan Gerung dan juga memiliki jumlah siswa yang berasal dari latar belakang agama, budaya dan adat istiadat yang berbeda-beda. ${ }^{3}$

Berdasarkan latar belakang tersebut peneliti mengangkat penelitian yang berjudul: Nilai Multikultural Dalam Pembelajaran PAI di Sekolah "Studi Terhadap Upaya Membina Karakter Siswa di SMKN 1 Gerung Kec. Gerung Kab. Lombok Barat Tahun 2018”. dengan harapan dapat menghasilkan penelitian yang baik, berkualitas dan dapat memberikan sumbangsih pada pengelolaan pendidikan.

Berdasarkan uraian latar belakang di atas, maka rumusan masalah yang dapat diambil adalah: Apasaja nilai-nilai multikultural yang terdapat dalam pembelajaran PAI di SMKN 1 Gerung Kec. Gerung Kab. Lombok Barat? Bagaimanakah proses penanaman nilai-nilai multikultural dalam pembelajaran PAI di SMKN 1 Gerung Kec. Gerung Kab. Lombok Barat? Bagaimanakah metode pembinaan karakter melalui nilai-nilai multikulturalal dalam pembelajaran PAI di SMKN 1 Gerung Kec. Gerung Kab. Lombok Barat?

2 Zakiyuddin Baidhawy, Pendidikan Agama Berwawasan Multikultural (Jakarta: Penerbit Erlangga, 2005), 120.

${ }^{3}$ Observasi awal, pada tanggal 8 Maret 2018. 


\section{METODE PENELITIAN}

Pendekatan yang digunakan dalam penelitian ini adalah pendekatan kualitatif dengan jenis penelitian field research. Lokasi penelitian bertempat di SMKN 1 dalam kurun waktu tahun 2018.

Sumber data pada penelitian ini yaitu sumber data primer dan sekunder, sumber data primer adalah: hasil wawancara dengan kepala sekolah, guru PAI, waka kurikulum, waka kesiswaan, siswa dan pegawai perpustakaan SMKN 1 Gerung Lombok Barat. Sumber data sekunder adalah sumber yang secara tidak langsung memberikan data kepada pengumpulan data, misalnya lewat orang lain atau dokumen.

Untuk memperoleh data di lapangan dalam rangka menganalisis dan menjawab permasalahan yang terangkum dalam permasalahan penelitian, maka metode yang digunakan dalam penelitian ini adalah sebagai berikut:

a. Observasi

Peneliti menggunakan metode ini untuk mengamati secara langsung di lapangan, terutama data tentang letak geografis dan keadaan fisik SMKN 1 Gerung, kegiatan pembelajaran proses penanaman nilai multikultural PAI, fasilitas/sarana prasarana pendidikan yang ada di SMKN 1 Gerung Lombok Barat.

b. Wawancara

Wawancara dalam penelitian ini dilakukan dengan pihak-pihak terkait, seperti: kepala sekolah, guru Pendidikan Agama Islam (PAI), wakil kepala sekolah, dan siswa SMKN 1 Gerung.

c. Dokumentasi

Metode dokumentasi digunakan peneliti untuk memperoleh data yang terkait dengan sejarah berdirinya SMKN 1 Gerung, profil, visi, misi, tujuan dan kebijakan umum keadaan guru dan siswa, sarana prasarana, serta proses pembelajarannya.

Setelah data yang diperlukan sudah terkumpul, maka langkah selanjutnya adalah melakukan analisis atau pengelolaan data sesuai dengan jenis datanya. Bahwa analisis data dimulai dengan menelaah seluruh data yang tersedia dari berbagai sumber, yaitu dari wawancara, pengamatan yang sudah dituliskan dalam catatan pribadi, dokumen resmi, gambar, foto, dan sebagainya.

Aktivitas dalam analisis meliputi: reduksi data (data reduction); penyajian data (data display); serta penarikan kesimpulan dan verifikasi (conclusion drawing/ verification).

Agar data yang diperoleh menjadi lebih absah dan valid, maka peneliti perlu melakukan pengecekan keabsahan data dengan cara ketekunan/keajengan pengamatan, trianggulasi data, dan perpanjangan keikutsertaan peneliti. 


\section{HASIL DAN PEMBAHASAN}

\section{Proses penanaman nilai-nilai multikultural di dalam kelas}

Kemampuan guru dalam mengajarkan materi tentang toleransi, kerukunan dan kesetaraan sangat baik. Hal ini terlihat saat guru menjelaskan kepada peserta didik, guru selain memakai surat Al Kaafirun dan surat Al Hujurat ayat 13, ia juga memakai ayat pendukung yaitu memakai surat Yunus ayat $99^{4}$ dan hadits tentang piagam madinah.

Materi ajar yang dikembangkan guru disesuaikan dengan mata pelajaran dan sesuai dengan Rencana Pelaksanaan Pembelajaran (RPP) yang sudah dibuat. Materi yang disampaikan guru dalam menanamkan nilai-nilai multikultural diantaranya:

a. Pengertian toleransi, kerukunan dan kesetaraan dengan tujuan agar siswa memiliki pengetahuan tentang toleransi, kerukunan dan kesetaraan. Guru memberikan pemahaman kepada para siswa bahwa kita hidup dalam negara demokrasi yang dituntut untuk selalu bersikap toleran dan humanis, yaitu sikap saling menghormati, dan menghargai keberagaman serta memandang bahwa perbedaan merupakan sebuah keniscayaan dari Tuhan.

b. Penyampaian konsep toleransi, kerukunan dan kesetaraan dalam Islam dengan menyampaikan dasar yang bersumber dari Al-Qur'an dan hadits.

\section{Metode dalam Menanamkan Nilai-Nilai Multikultural di Kelas}

Model pembelajaran PAI di SMKN 1 Gerung dalam menanamkan nilai-nilai multikultural (toleransi dan kesetaraan) menggunakan model pengajaran aktif dan kooperatif dengan menggunakan metode: a). Metode diskusi dan b). Metode tanya jawab. ${ }^{5}$ Implementasinya pada proses pembelajaran melalui tahapan-tahapan sebagai berikut:

1. Merumuskan tujuan pembelajaran.

Guru memberikan wawasan kepada semua siswa sebelum pembelajaran dimulai bahwa tujuan dari belajar PAI pada bab Akhlaq dengan tema toleransi dan kerukunan (diperdalam peneliti dengan materi kesetaraan) adalah agar terbiasa untuk dilakukan dalam bersosialisasi baik di sekolah, rumah dan masyarakat". 6 Teknik yang dipergunakan sebagai berikut:

a) Menanyakan pada peserta didik pembelajaran yang telah lalu.

b) Menyampaikan secara gamblang tujuan pembelajaran dengan metode diskusi.

c) Menyampaikan arti dan manfaat pembelajaran tersebut kepada peserta didik.

\footnotetext{
${ }^{4}$ Kemenag, Al-Qur'an Terjemah Bahasa Indonesia (QS. Yunus/10:99)

${ }^{5}$ Hasil wawancara peneliti dengan guru PAI tanggal 13 September 2018.

${ }^{6}$ Hasil wawancara dengan guru PAI tanggal 13 September 2018
} 
2. Menentukan mekanisme dan tata tertib diskusi

Disini guru PAI membuat mekanisme dan tata tertib metode diskusi secara tertulis ataupun lisan. untuk presentasi”.

3. Merumuskan masalah atau topik diskusi

Untuk keberhasilan diskusi, maka masalah atau topik yang harus mempermasalahkan topik- topik yang memang memerlukan pemikiran diskusi antara pihak-pihak yang terlibat. Topik yang akan didiskusikan ialah indikator yang sudah dijabarkan peneliti menjadi angket, satu kelompok mendapatkan satu tema secara acak untuk dijelaskan dan didiskusikan dalam mensikapinya.

4. Mengatur kelompok-kelompok diskusi

Kelompok yang sudah terbentuk dan sudah dipilih ketua, sekretaris dan pelapor mendiskusikan materi yang sudah mereka dapatkan secara acak tadi. Disini guru menjadi pengatur jalannya diskusi agar berjalan sesuai dengan rencana. Kelima Melaksanakan Diskusi. Diantara tanggapan ketika diskusi sedang berlangsung ialah mengapa orang Indonesia sering ribut atas dasar agama, dicontohkan orang sedang shalat/beribadah tempat ibadahnya di bom padahal mereka sudah diajarkan untuk menghormati orang lain yang beribadah sesuai yang dianutnya?"7. Setelah peneliti bertemu dengan siswa yang tadi menjadi bahan pembicaraan, ternyata memang benar bahwa anak itu kurang menghargai dirinya sendiri, terbukti dengan indikasi bahwa dari sisi pakaian kurang rapi, bajunya keluar, dia tidak pakai kaos kaki, dia sudah biasa merokok, dan motornya di modif tapi modif knalpot bising ${ }^{8}$. Dikelompok terakhir dengan tema (Memandang meski beda kultur, tapi tetap saudara sebangsa dan setanah air) disesi ini diskusi berjalan hamper seperti pada sesi pertama, dimana diskusi kurang terihat efektif, kelompok yang lain kurang aktif dalam memberikan tanggapan.

\section{Metode pembinaan karakter dalam pembelajaran PAI}

Pengimplementasian pendidikan karakter berbasis multikultural di sekolah memerlukan strategi yang tepat, efektif, dan partisipatif melibatkan seluruh komponen pendidikan. Ketepatan pemilihan strategi akan memberikan hasil yang optimal dalam membentuk peserta didik yang berkarakter. Dengan demikian upaya pengembangan model-model pendidikan karakter sebagai sebuah strategi pengimplementasian pendidikan karakter berbasis multikultural sangat penting dilakukan.

Pengembangan model pendidikan karakter harus didasarkan pada prinsip-prinsip pendidikan karakter sebagai berikut.

\footnotetext{
${ }^{7}$ Hasil wawancara peneliti dengan siswa kelas XI saat pelajaran PAI tanggal 13 September 2018

${ }^{8}$ Hasil observasi peneliti dengan salah satu siswa kelas XII, tanggal 14 September 2018.
} 
1. Mempromosikan nilai-nilai dasar etika sebagai basis karakter.

2. Mengidentifikasi karakter secara komprehensif supaya mencakup pemikiran, perasaan, dan perilaku.

3. Menggunakan pendekatan yang tajam, proaktif dan efektif untuk membangun karakter.

4. Menciptakan komunitas sekolah yang memiliki kepedulian.

5. Memberi kesempatan kepada peserta didik untuk menunjukkan perilaku yang baik.

6. Memiliki cakupan terhadap kurikulum yang bermakna dan menantang yang menghargai semua peserta didik, membangun karakter mereka, dan membantu mereka untuk sukses.

7. Mengusahakan tumbuhnya motivasi diri pada para peserta didik.

8. Memfungsikan seluruh staf sekolah sebagai komunitas moral yang berbagi tanggung jawab untuk pendidikan karakter dan setia pada nilai dasar yang sama.

9. Adanya pembagian kepemimpinan moral dan dukungan luas dalam membangun inisiatif pendidikan karakter.

10. Memfungsikan keluarga dan anggota masyarakat sebagai mitra dalam usaha membangun karakter.

11. Mengevaluasi karakter sekolah, fungsi staf sekolah sebagai guru-guru karakter, dan manifestasi karakter posisitf dalam kehidupan peserta didik. ${ }^{?}$

Begitu pula halnya Pengembangan model pendidikan karakter berbasis multikultural hendaklah menerapkan prinsip integratif, kompak, dan konsisten. Pengembangan model yang demikian memiliki ciri-ciri sebagai berikut:

Pertama, integratif yaitu mengintegrasikan pendidikan karakter berbasis multikultural ke dalam seluruh kegiatan di sekolah, baik kegiatan kurikuler, ekstrakurikuler, maupun pengembangan diri. Selain itu, mengintegrasikan pula pendidikan karakter berbasis multikultural ke dalam perencanaan program, pelaksanaan, dan evaluasi. Dengan demikian seluruh kegiatan sekolah, mulai dari proses pembelajaran seluruh mata pelajaran di kelas maupun kegiatan ekstrakurikuler dan pengembangan diri yang dilakukan di luar kelas, senantiasa diwarnai oleh pendidikan karakter berbasis multikultural.

Kedua, kompak yaitu seluruh komponen pendidikan di sekolah, termasuk orang tua siswa, memiliki pandangan dan langkah yang kompak dalam mengimplementasikan pendidikan karakter berbasis multikultural. Komponen pendidikan yang memiliki andil besar dalam penerapan pendidikan karakter antara lain: pendidik, kepala sekolah, tenaga kependidikan, komite sekolah, orang tua siswa, dan masyarakat. Kekompakan dapat

\footnotetext{
${ }^{9}$ Kementerian Pendidikan Nasional. Panduan Pendidikan Karakter. (Jakarta:Kemdiknas, 2010). h. 23.
} 
diwujudkan manakala jalinan komunikasi antar-komponen tersebut berlangsung secara baik dan konstruktif.

Ketiga, konsisten yaitu seluruh komponen pendidikan memiliki sikap yang konsisten dalam menerapkan pendidikan karakter berbasis multikultural di sekolah. Perlakuan sekaligus penghargaan yang sama terhadap seluruh siswa tanpa memandang perbedaan status sosial, etnis, agama, dan suku harus secara konsisten diterapkan.

Tiga ciri tersebut bersimultan saling melengkapi untuk mewujudkan pendidikan karakter berbasis multikultural dengan memperhatikan prinsip-prinsip pendidikan karakter berbasis multikultural ke-Indonesiaan, seperti penjelasan berikut yaitu:

a. Pendidikan karakter berbasis multikultural sebaiknya dimulai dari diri sendiri. Prinsip ini menekankan bahwa pendidikan karakter berbasis multikultural harus dimulai dari pengenalan terhadap jati diri sendiri. Penanaman bahwa diri peserta didik merupakan bagian dari warga bangsa merupakan hal penting. Rasa bangga sebagai warga bangsa Indonesia harus menjadi pijakan.

b. Pendidikan karakter berbasis multikultural hendaknya dikembangkan agar pembelajar tidak mengembangkan sikap etnosentris kesukuan dan sebaliknya membangun kesadaran hidup dalam lingkup kebangsa-Indonesiaan. Dengan mengembangkan sikap yang non-etnosentris, kebencian dan konflik antaretnis dapat dihindarkan karena perasaan satu bangsa. Pendidikan pendidikan karakter berbasis multikultural bertujuan membangun kesadaran yang tidak bersifat egosentris yang mengunggulkan diri dan kelompoknya dan merendahkan kelompok lain. Kesadaran satu bangsa meski berbeda kelompok sosial merupakan hal penting untuk ditumbuhkembangkan sebagai jembatan jiwa nasionalisme.

c. Pendidikan karakter berbasis multikultural dikembangkan secara integratif. Kurikulum pendidikan karakter berbasis multikultural menjangkau seluruh isi pendidikan. Kurikulum pendidikan multikultural harus terintegrasi ke dalam semua mata pelajaran, seperti bahasa, ilmu pengetahuan sosial, sains, pendidikan jasmani, kesenian, dan mata pelajaran lainnya.

d. Pendidikan karakter berbasis multikultural harus menghasilkan sebuah perubahan dalam bentuk perubahan sikap melalui pembiasaan. Praktik pembelajaran didesain dalam suasana masyarakat belajar yang menghargai perbedaan, toleransi, dan tujuan bersama mencintai bangsa dan negara. Untuk mencapai suasana demikian, pembelajaran harus berorientasi pada proses, misalnya bermain peran, simulasi, diskusi, pembelajaran kooperatif, dan pembelajaran partisipatoris.

e. Pendidikan karakter berbasis multikultural harus mencakup realitas sosial dan kesejarahan dari agama, etnis, dan suku yang ada. Kontekstualisasi pendidikan multikultural harus bersifat lokal, nasional, dan global. Kebanggaan memiliki nilai 
kearifan lokal harus ditumbuhkan. Kesadaran nasionalisme harus menjadi tujuan bersama pendidikan nasional. Kesadaran sebagai warga global dengan menjunjung tinggi nilai-nilai perdamaian antarbangsa perlu dikembangkan. Kontekstualisasi semacam ini memiliki makna penting untuk menumbuhkan rasa hormat, toleran, dan menghargai keberagaman dalam lingkup kelompok sosial masyarakat, negara, dan dunia. ${ }^{10}$

Sementara itu, di SKN 1 Gerung juga berusaha untuk senantiasa menanamkan nilai multi cultural dalam segala aspek pada peserta didiknya ketika mereka berada di lingkungan sekolah, sebagai mana yang disampaikan oleh bapak kepala sekolah: Siswa SMKN 1 Gerung selalu kompak dalam berkegiatan baik yang berupa kegiatan internal maupun eksternal, mereka juga selalu berusaha untuk mengintegrasikan kegiatan mereka dengan nilai-nilai karakter dan nilai kultur. Untuk membuktikan kekompakan mereka tambah kepala sekolah bisa dilihat/dibuktikan pada saat mereka bekerja sama dalam membuat dan membersihkan taman yang ada di lingkungan sekolah mereka, juga pada saat mereka melakukan praktikum, kekopakan mereka sangat jelas, kondisi seperti ini imbuh kepala sekolah kami sangat menjaganya, karena dengan menanamkan nilai-nilai seperti ini pertumbuhan dan perkembangan sekolah terkait emosinal peserta didik sangat baik dan efektif untuk menjaga keharmonisan siswa/peserta didik. ${ }^{11}$

\section{Peran Guru dalam Pengembangan Model Pendidikan Karakter Berbasis Multikultural}

Prinsip-prinsip pengembangan model pendidikan karakter berbasis multikultural terimplementasikan ke dalam perilaku keteladanan para tokoh yang memiliki pengaruh kuat pada diri peserta didik. Salah satu tokoh acuan peserta didik dalam berperilaku adalah guru. Guru hendaknya bertindak sebagai role mode, suri teladan bagi kehidupan sosial akademis siswa, baik di dalam maupun di luar kelas. ${ }^{12}$ Pendidikan karakter berbasis multikultural memiliki semangat mengakui dan menghargai perbedaan-perbedaan kultural dan kontribusikontribusinya terhadap cara hidup masyarakat. Upaya terpenting dalam menerapkan pendidikan semacam ini adalah melalui pengajaran yang responsif secara kultural. Di sinilah pentingnya peran guru dalam pengembangan model pendidikan karakter tersebut. Jacobsen mengemukakan bahwa pengajaran responsif secara kultural (culturally responsive teaching)

\footnotetext{
${ }^{10}$ Sariban. "Pendidikan Multikultural Pembentuk Karakter Ke-Indonesiaan". Makalah. www.gurupintar.ut.ac.id (diunduh tanggal 12 November 2018).

11 Drs. H. Zaenal Arifin, M.Si. Kepala Sekolah SMKN 1 Gerung, wawancara tanggal 22 September 2018.

12 Mas'ud, Abdurrahman. Menggagas Format Pendidikan Nondikotomik. (Yogyakarta: Gama Media, 2003). h. 202 .
} 
merupakan pengajaran yang mengakui dan mengakomodasi keragaman kultural di dalam ruang kelas. ${ }^{13}$

SMKN 1 Gerung mengedepankan nilai-nilai multicultural dalam upaya membina karakter siswa dan menerapkan model pembelajaran yang bersifat responsive, karena pengajaran yang bersifat responsif secara cultural mencakup hal-hal sebagai berikut, yaitu:

1. Menciptakan lingkungan kelas yang positif di mana seluruh siswa dihargai dan dihormati.

2. Mengomunikasikan harapan-harapan yang positif untuk pembelajaran seluruh siswa.

3. Mengakui keragaman kultural dalam diri siswa dan mengintegrasikan keragaman ini ke dalam kurikulum.

4. Menggunakan strategi-strategi pengajaran yang memberdayakan latar belakang dan kekuatan siswa.

5. Model pembinaan karakter siswa SMKN berbasis pendidikan agama Variasi itu dapat dilihat dari dua model: Model Kurikuler dan Model Pengembangan Kultur Sekolah. Model Kurikuler meliputi kegiatan intrakurikuler, kokurikuler, dan ekstrakurikuler.

6. Pembinaan karakter siswa dengan model intrakurikuler ditekankan dalam prosesproses pembelajaran Pendidikan Agama baik di dalam ruang kelas maupun di luar ruang kelas. Model ini sangat umum diikuti oleh masing-masing sekolah. Namun, yang penting untuk dicermati ialah bahwa program intrakurikuler untuk pembinaan karakter siswa dirancang sedemikian rupa dengan mengintegrasikan nilai-nilai karakter tertentu ke dalam dokumen silabus maupun Rencana Pelaksanaan Pembelajaran. ${ }^{14}$

Jelaslah bahwa guru sangat berkepentingan untuk menciptakan suasana dan lingkungan kelas yang membuat seluruh siswa merasa dihargai sehingga memunculkan harapan-harapan positif. Guru multikultural yang efektif secara aktif memperkenalkan keragaman budaya dan menanggapinya di dalam ruang kelas melalui model-model pembelajaran yang melibatkan seluruh siswa dari berbagai latar belakang dan pengalaman.

Penanaman nilai-nilai multikultural dalam kehidupan beragama seharusnya tidak berhenti pada upaya-upaya yang dilakukan sekolah dalam mengenalkan siswa kepada keberagamaan yang sudah menjadi keniscayaan dalam kehidupan, tetapi siswa juga perlu mampu menghayati dan memahami akan pentingnya nilai-nilai multikultural dalam kehidupan ini. Karena itulah penempatan siswa dikelas tidak mengelompokkannya berdasarkan kelompok agama dan asal siswa sebagaimana yang disampaikan bapak kepala SMKN 1 Gerung sebagai berikut :" Penempatan siswa di kelas tidak memandang agama siswa,

${ }^{13}$ Jacobsen, David A., Paul Eggen, Donald Kauchak. Methods for Teaching. (Yogyakarta: Pustaka Pelajar. 2009). h. 262.

${ }^{14}$ Hidayatul Amni, S.Pd.I. Guru PAI. wawancara, Selasa tanggal 22 September 2018 
sehingga dalam satu kelas terdapat siswa yang beragama Islam, Hindu dan Budha. ${ }^{15}$ Dalam hubungannya dengan pendidikan agama Islam, ketika guru mengajarkan PAI, siswa yang non muslim diperbolehkan ikut terutama bagi mereka yang mau belajar agama Islam, namun biasanya para siswa non muslim keluar dan belajar di perpustakaan ${ }^{16}$

Peneliti melihat bahwa siswa SMKN 1 Gerung mampu memahami dan menghayati akan pentingnya nilai-nilai pendidikan multikultural dalam kehidupan beragama. Hal ini tampak dari pandangan siswa tentang toleransi. Dalam hal ini peneliti paparkan sebagai berikut:

1. Siswa SMKN 1 Gerung memandang bahwa toleransi antar umat beragama dalam pergaulan sehari-hari adalah penting karena agama mengajarkan untuk berbuat baik kepada semua manusia. Selain itu pihak sekolah juga mengajarkan agar siswa berbuat baik kepada sesama. Sehubungan dengan hal tesebut peneliti melakukan wawancara kepada beberapa siswa SMKN 1 Gerung, yang hasilnya sebagai berikut:

“ Toleransi penting diterapkan dalam kehidupan kita sehari-hari, apalagi di SMKN 1 Gerung yang siswanya berasal dari agama yang bermacam-macam ada muslim dan ada juga Hindu".17

“Toleransi memang sangat perlu diterapkan dalam kehidupan kita sehari-hari, apalagi di SMKN 1 Gerung yang siswanya berasal dari agama yang bermacam-macam”.18

“Toleransi sangat perlu diterapkan dalam kehidupan kita sehari-hari, kita disini ”.19

"Bagi saya toleransi sangat perlu diterapkan dalam kehidupan kita sehari-hari, terutama bagi kita disini ".20“

"Oo ya bagi saya toleransi sangat perlu diterapkan dalam kehidupan kita sehari-hari, sebab kalau tidak ada toleransi sekolah kita bisa kacau terutama bagi kita disini ".21

"Menurut saya toleransi itu penting sekali, karena untuk mempererat persaudaraan kita".22

"Siswa di sekolah kami berasal dari berbagai macam agama, jadi toleransi itu penting diterapkan agar kita bisa hidup rukun".23

“Toleransi itu penting, karena menurut ajaran agama kita seperti itu, kita harus berbuat baik kepada orang lain”.24

"Menurut saya toleransi itu penting sekali, karena untuk mempererat persaudaraan kita".25

"Siswa di sekolah kami berasal dari berbagai macam agama, jadi toleransi itu penting diterapkan agar kita bisa hidup rukun".26

"Toleransi itu penting, karena menurut ajaran agama kita seperti itu, kita harus berbuat baik kepada orang lain”.27

\footnotetext{
15. Abdullah. S. Pd. Wawancara, Jumat, tanggal 22 September 2018

16. Observasi hari selasa, tanggal 26 September 2018

17. Ilham Ari Topan, kelas XII/A,W awancara, 27 September 2018

18. I Made Juniarta, kelas XII/b,Wawancara, 27 September 2018

19. Ibnu Akmal, kelas XII/C , kelas VII/b,Wawancara, 27 September 2018

${ }^{20}$ Helmawan Sapdan Hadi, kelas X/C, kelas XII/b,W awancara, 27 September 2018

${ }^{21}$ Hiru Zindani kelas XII/A,Wawancara, 27 September 2018

22 Hamdani, kelas X/b, Wawancara, 27 September 2018

23 Jiril Anwar, kelas X/b, Wawancara, 27 September 2018

24Irnawati, kelas X/d, Wawancara, 27 September 2018

${ }^{25}$ M. Ya'kub, kelas XIII/b, Wawancara, 27 September 2018

${ }^{26}$ Khaerul Patoni, kelas XIII/b, Wawancara, 27 September 2018

27 Maesarah kelas XI/d, Wawancara, 27 September 2018
} 
Siswa SMKN 1 Gerung menganggap perlu dan penting terhadap usaha-usaha kerjasama antar umat beragama dalam kehidupan sehari-hari. Data ini peneliti peroleh dengan melakukan wawancara dengan beberapa siswa SMKN 1 Gerung yang hasilnya sebagai berikut:

"Menurut saya kerjasama dengan semua teman tanpa memandang dia berasal dari mana dan beragama apa dalam pergaulan sehari-hari itu sangat bagus sekali, karena kita bisa bersatu".28

"Kita di sekolah ini sudah terbiasa hidup bersama-sama, dan menurut saya kerjasama dengan semua orang meskipun beda agama sangat penting sekali karena dapat mempererat tali persaudaraan kita".29

"Kerjasama dengan semua orang itu harus karena, kita tidak bisa hidup sendiri saja, kita butuh dengan orang lain juga". 30

2. Siswa SMKN 1 Gerung memandang bahwa kerukunan umat beragama untuk menjalin persahabatan sangat perlu dan penting adanya. Data ini peneliti peroleh dengan melakukan wawancara kepada beberapa siswa SMKN 1 Gerung dan hasilnya adalah sebagai berikut:

"Yang ada di sekolah ini kan bukan hanya siswa muslim saja, tapi ada yang beragama Hindu dan Budha. Jadi menurut saya kerukunan umat beragama untuk menjalin persahabatan itu sangat penting sekali, agar kita bisa hidup rukun satu sama lain". 31

Dengan menanamkan sikap toleransi yang baik pada peserta, diharapkan akan menjadi nilai karakter mereka dalam kehidupan sehari-hari selama mereka menuntut ilmu atau sekolah di SMKN 1 gerung. Di samping penjelasan sebagai mana gambaran di atas, untuk menanamkan nilai karakter melalui nilai pendidikan multikultural, juga menggunakan pendekatan dalam proses pembelajaran dan hal tersebut dapat dilihat pada penjelasan berikut:

\section{Aspek Pendekatan dalam Pembelajaran}

Berdasarkan penyajian data sebelumnya, guru pendidikan agama Islam dalam menumbuhkan toleransi siswa melalui pendidikan multikultural, dalam pembelajarannya tidak ada melakukan pendekatan secara khusus namun pendekatannya hanya bertumpu pada aspek-aspek dari masing-masing komponen pembelajaran dan kepada siswa yang non-Islam guru pendidikan agama Islam memberikan pilihan untuk mengikuti pelajaran pendidikan agama Islam atau boleh untuk memilih belajar di perpustakaan. Dan mengenai tujuan pembelajaran guru pendidikan agama Islam sebelum menyampaikan materi memang menyampaikan tujuan pembelajaran terlebih dahulu, sehingga apa yang diinginkan dari pembelajaran pendidikan agama Islam terlaksana dengan baik. Apalagi berhubungan dengan toleransi melalui pendidikan multikultural, terlihat guru menjelaskan tujuan pembelajaran dan membuka wawasan siswa tentang multikultural, sebab materi yang disampaikan berhubungan dengan wawasan multikultural.

\footnotetext{
28 I Made Suarjana, Kelas XII/a, Wawancara, 28 September 2018

${ }^{29}$ Muhammad Gazali, kelas XII/ a, W awancara, 28September 2018

${ }^{30}$ Niluh Suci, kelas XI/d,W awancara, 28 September 2018

31 Ilham Ari Topan kelas XII/a. wawancara, 28 September 2018
} 
Dalam memilih pendektan pembelajaran J.A.Bank menawarkan empat pendekatan dalam pendidikan multikultural yaitu: kontributif, aditif, aksi sosial, dan transformatif. Pendekatan kontributif adalah pendekatan yang dilakukan dengan cara menyeleksi buku-buku teks wajib atau anjuran dan aktivitas-aktivitas tertentu seperti hari-hari besar kenegaraan dan keagamaan dari berbagai macam kebudayaan. Sementara pendekatan aditif merupakan bentuk penambahan muatan-muatan, tema-tema dan perspektif-perspektif ke dalam kurikulum tanpa mengubah struktur dasarnya. Sedangkan pendekatan transformatif yaitu mengembangkan suatu paradigma baru bagi kurikulum atau membuat kurikulum baru di mana konsep-konsep, isu-isu, tema-tema, dan problem-problem didekati dengan pendektan muqaran (perbandingan) untuk memperbaharui pemahaman dan berbagai perspektif dan sudut pandang. Sementara pendekatan aksi sosial yaitu mengkombinasikan pendekatan transformatif dengan berbagai aktivitas untuk melakukan perubahan sosial. ${ }^{32}$

Dengan berbagai pendekatan guru bisa saja menambah materi Pendidikan Agama Islam (PAI) kebeberapa unit atau topik secara khusus yang berkaitan dengan materi multicultural. Namun suatu hal yang tidak boleh dilupakan oleh guru adalah memberikan keterangan dengan poin kunci pembelajaran dengan merefleksikan materi yang berbeda-beda. Secara khusus para guru menggabungkan materi-materi multikulturalisme ke dalam kurikulum dan atau konten pembelajaran dengan beberapa cara pandang yang beragam atau yang disebut Conten Integration 33

\section{Aspek Strategi dan Taktik dalam Pembelajaran}

Berdasarkan penyajian data sebelumnya guru selalu menggunakan strategi pembelajaran dengan baik termasuk dalam menumbuhkan toleransi siswa melalui pendidikan multikultural dalam pendidikan agama Islam. terlihat guru pendidikan agama Islam berusaha menemukan strategi pembelajaran yang tepat, terlebih membuka wawasan siswa terhadap materi pendidikan agama Islam yang berhubungan dengan wawasan multikultural.

Pada intinya pendidikan multikultural bukan merupakan suatu bentuk pendidikan monokultur, akan tetapi model pendidikan yang berjalan di atas rel keragaman sehingga strategi yang menurut guru memiliki hubungan dengan multikultural dicontohkan dengan pembagian kelompok yang disesuaikan dengan karakteristik siswa agar menciptakan kekompakan siswa dalam belajar tanpa memandang latar belakang budaya, suku dan agama.

Dalam kegiatan pembelajaran kelompok guru membantu siswa untuk memahami beberapa persefektif dan merumuskan kesimpulan yang dipengaruhi oleh disiplin

32 Sulalah, Pendidikan Multikultural, h. 126-127

${ }_{33}$ James A. Banks, Multicultural Education, Historical Development, Dimensions and Practices, Review Of Reasearch In Education In Opening The Doors to Opportunity All, Setting Research Agenda For TheFuture, American InstituteFor Research (AIR), 2015, volume 19,1993. P. 54 Accessed In www.air.og. 14/9/2018 
pengetahuan yang mereka miliki termasuk bagaimana guru membantu siswa agar para siswa menyadari betapa perubahan-perubahan prilaku siswa itu terjadi karena perubahan pengtahuan yang ada pada diri mereka sendiri.

Teknik dan strategi pembelajaran yang dikembangkan oleh guru dalam hubungannya dengan multikultural adalah sesuatu yang berhubungan dengan sejauhmana guru membantu siswa faham dan menyelidiki dan untuk menentukan bagaimana asumsi budaya belajar yang tersurat dan tersirat, kerangka acuan, persefektif dan prasangka didalam disiplin belajar yang mempengaruhi bagaimana cara pengetahuan disusun didalamnya yang berkaitan dengan pengaruh perubahan pengetahuan yang ada pada diri siswa itu sendiri yang disebut knowledge contraktion $^{34}$

Di dalam kegiatan pembelajaran adalah dengan pemberian motivasi kepada siswa, peranan motivasi sangat diperlukan. Dengan motivasi, siswa dapat mengembangkan aktivitas, dapat mengarahkan dan memelihara ketekunan dalam melakukan kegiatan belajar. Salah satunya adalah dengan memotivasi siswa untuk giat belajar, sebelum seorang guru memberikan motivasi kepada siswa, ada hal-hal yang harus diperhatikan dalam pemberian motivasi tersebut. Rapunandojo memberikan beberapa hal yang perlu diperhatikan dalam memberikan motivasi seperti berikut ini:

a) Adanya perbedaan individu baik secara fisik maupun emosional.

b) Setiap individu memiliki kepribadian yang unik.

c) Semua perilaku terjadi akibat adanya perubahan baik dalam diri individu maupun dalam situasi yang dihadapinya.

d) Setiap individu memiliki rasa ego yang cendrung mengabaikan kepetingan orang lain.

e) Emosi seseorang biasanya dengan mudah dikenali dan sangat dominan dalam membentuk perilaku seseorang.

f) Jarang mengetahui kondisi secara mendalam. ${ }^{35}$

Dalam proses pembelajaran guru tidak hanya menguasai strategi pengorganisasian isi pembelajaran saja, tetapi gurupun harus mampu menguasai dan menerapkan strategi pengelolaan pembelajaran. Pengelolaan motivasional terkait dengan usaha untuk memotivasi siswa dalam kegiatan pembelajaran. Apabila motivasi belajar siswa rendah maka strategi apapun yang digunakan dalam pembelajaran tidak akan mampu meningkatkan hasil belajar siswa. Setiap strategi pembelajaran tidak akan mampu meningkatkan hasil belajar siswa. Setiap strategi pembelajaran pada dasarnya secara implisit telah mengandung komponen motivasional, walaupun dengan cara yang berbeda-beda. Selain itu juga mengelompokkan

34 Abdurrahman Gintings, Esensi Praktis Belajar Pembelajaran, dipersiapkan untuk pendidikan Profesi Guru dan Dosen, Cet ke 2, (Bandung: Humaniora, 2008), h. 99

35 Ibid, h. 101 
siswa sesuai dengan karakteristik mereka, serta menjadikan diri sebagai teladan bagi siswa, ini menunjukkan usaha yang dilakukan oleh guru benar-benar sudah maksimal.

\section{Aspek Metode dan Teknik dalam Pembelajaran}

Berdasarkan penyajian data sebelumnya terlihat guru selalu berusaha menciptakan suasana belajar dengan baik dengan menggunakan berbagai macam metode dalam setiap pertemuannya, ini dimaksudkan agar konsep pembelajaran pendidikan agama Islam yang berhubungan dengan wawasan multikultural bisa tersampaikan dengan baik.

Adapun mengenai metode pembelajaran guru harus fokus pada karakteristik dari sikap rasial siswa dan bagaimana sikap tersebut dapat diubah dengan metode dan materi pelajaran. Guru harus banyak menggunakan teknik dalam mengembangkan prilaku positif pada diri siswa. Sebagai contoh ketika anak-anak masuk sekolah dengan prilaku negative dan memiliki kesalah pahaman terhadap ras/ atau etnik lainnya, maka pendidikan dapat membantu siswa mengembangkan prilaku integratif yang lebih positif, penyediaan kondisi yang lebih mapan dan pasti. Dua kondisi yang dimaksud adalah bahan pembelajaran yang memiliki citra positif tentang perbedaan kelompok dan menggunakan bahan pembelajaran tersebut secara konsisten dan terus menerus.

Kita dapat menyaksikan pada layar TV maupun kita baca lewat media cetak dan elektronik betapa banyak siswa melakukan perkelahian maupun tawuran antar pelajar, ini membuktikan bahwa para pelajar yang datang kesekolah dengan banyak streotipe cendrung berprilaku negatif dan banyak melakukan kesalah fahaman terhadap kelompok etnik dan ras dari luar kelompoknya karena itulah guru dituntut untuk melakukan dan merekontruksi metode maupun teknik penyampaian bahan pelajaran yang lebih koopratif yang diharapkan dapat membantu para siswa untuk mengembangkan prilaku dan persepsi terhadap ras maupun kelompok lebih positif. Jenis strategi dan bahan dapat menghasilkan pilihan dalam diri siswa untuk lebih bersahabat dengan ras luar, etnik dan kelompok budaya lain.

Dalam memilih metode mengajar harus memperhatikan dasar pertimbangan memilih metode mengajar. Dasar pertimbangan itu berasal dari: 1. Berpedoman pada tujuan, 2. Perbedaan Individual siswa, 3. Kemampuan guru, 4. Sifat materi pelajaran, 5. Situasi kelas, 6. Kelengkapan fasilitas, 7. Kelebihan dan kekurangan metode.

Dalam kegiatan pokok inilah diharapkan terjadinya interaksi edukatif yang optimal antara guru dan siswa, interaksi yang dikehendaki adalah multi arah. Setiap siswa mempunyai kesempatan yang sama untuk diperhatikan, dikembangkan dan diberdayakan potensinya. Dalam pembelajaran, harus memberikan pengalaman yang bervariasi dengan metode efektif dan bervariasi. Dalam penggunaan metode yang tepat akan turut menentukan efektivitas dan efesiensi pembelajaran. Dalam pembelajaran pendidikan agama Islam perlu ada sedikit ceramah dan metode-metode yang berpusat pada guru pendidikan agama Islam, serta lebih 
menekankan pada interaksi siswa terutama dengan metode diskusi dan kerja kelompok. Dengan penggunaan metode bervariasi inilah para siswa diharapkan termotivasi untuk belajar dan tujuan pembelajaran akan tercapai.

Dengan metode yang bervariasi guru melakukan banyak usaha untuk membantu siswa mengembangkan prilaku positif tentang perbedaan kelompok, menghargai pendapat temannya, menghormati sikap anggota kelompok yang berbeda, mengurai prasangka negative anggota sehingga terbangun komunikasi harmonis dikalangan peserta didik. Kondisi sebagaimana yang dimaksud di atas sesuai dengan pendapat James A. Banks yaitu dimensi pengurangan prasangka (Prejudice reduction) ${ }^{36}$

\section{Prosedur Berlangsungnya Pembelajaran}

Berdasarkan penyajian data sebelumnya, guru berusaha menciptakan suasana belajar yang kondusif dengan membangkitkan semangat belajar siswa selain itu, guru juga bersikap ramah dan hangat ketika berinteraksi dengan siswa sehingga menjadikan siswa respontif dan termotivasi dalam proses pembelajaran, dalam kaitannya dengan multikultural guru berusaha menyampaikan materi dengan lebih hati-hati, agar konsep multikultural bisa diserap dan dipahami siswa dan tidak dalam pengertian lain.

Proses pelaksanaan pembelajaran atau dikenal dengan istilah kegiatan belajar mengajar (KBM) merupakan komponen yang paling penting dalam pembelajaran. Agar pembelajaran menyenangkan guru harus tampil semangat, antusias dan gembira, menciptakan suasana pembelajaran yang kondusif, serta memanfaatkan energizer dan humor, memperlakukan peserta didik setara, adil dalam pendidikan termasuk dalam pedagogi ini ketika guru mengubah pengajaran mereka ke cara yang akan memfasilitasi akademik dari siswa dari berbagai kelompok ras, budaya dan kelas sosial. Karena itu, guru dituntut untuk menggunakan beragam gaya mengajar yang konsisten dengan banyaknya gaya belajar di dalam berbagai kelompok budaya dan ras.

Selain itu, guru hendaknya memperhatikan cara-cara dalam mengubah fasilitas pembelajaran sehingga mempermudah pencapain hasil belajar pada sejumlah siswa dari berbagai kelompok. Strategi dan aktivitas belajar yang digunakan sebagai upaya memberlakukan pendidikan secara adil antara lain denga bentuk kerjasama (cooperative learning) dan bukan dengan cara-cara yang kompetitif (competion learning) sehingga dalam proses pembelajaran guru-guru atau pihak sekolah dapat merancang kegiatan pembelajaran baik di kelas maupun suasana lingkungan sekolah menjadi banyak jenis kelompok termasuk kelompok etnik wanita, dan para pelajar dengan kebutuha khusus yang akan memberikan

\footnotetext{
${ }^{36}$.James A. Banks, Multicultural .....
} 
pengalaman pendidikan persamaan hak dan persamaan kesempatan belajar yang oleh Jame A Bank sebagai dimensi equitable pedagogy ${ }^{37}$

Melalui penciptaan suasana belajar yang efektif dan lingkungan belajar yang kondusif siswa akan dapat belajar dengan baik berada dalam suasana yang menyenangkan, merasa aman, yaman, memporoleh rasa keadilan, bebas dari rasa takut. Ini menunjukkan bahwa proses pembelajaran pendidikan agama Islam terlaksana dengan baik.

Dalam pembelajaran perlu dikondisikan sedemikian rupa sehingga siswa belajar dengan menyenangkan, untuk itulah perlu diadakan kesepakatan bersama antara guru dan siswa supaya dapat memperhatikan apa yang menjadi tugas dan kewajibannya.

\section{SIMPULAN}

Nilai multikultural yang terdapat dalam mata pelajaran PAI di SMKN 1 Gerung yaitu nilai religius, toleransi, demokratis, dan nilai cinta damai. Dari keempat nilai inti tersebut akan membentuk seseorang menjadi pribadi yang menghargai perbedaan, menghormati kepercayaan ataupun keyakinan orang lain, bersikap baik dengan semua orang, dan mampu hidup berdampingan dengan orang yang berbeda suku, agama, ras, dan budaya.

Proses penanaman nilai multikultural pada siswa SMK 1 Gerung dititiktekankan pada proses pembelajaran dengan menerapkan model pembelajaran yang bersifat responsive dan berbasis pendidikan Variasi, sehingga dapat menciptakan kultur lingkungan kelas yang kondosip.

Pengimplementasian pendidikan karakter berbasis multikultural di sekolah memerlukan strategi yang tepat, efektif, partisipatif, dan melibatkan seluruh komponen pendidikan. Ketepatan pemilihan strategi akan memberikan hasil yang optimal dalam membentuk peserta didik yang berkarakter. Dengan demikian upaya pengembangan model-model pendidikan karakter sebagai sebuah strategi pengimplementasian pendidikan karakter berbasis multikultural sangat penting dilakukan.

\section{DAFTAR PUSTAKA}

Gintings, Abdurrahman. 2008. Esensi Praktis Belajar Pembelajaran, dipersiapkan untuk pendidikan Profesi Guru dan Dosen, Cet ke 2. Bandung: Humaniora.

Arikunto, Suharsimi. 1986. Prosudur Penelitian: Suatu Pendekatan Praktek. Jakarta: Rineka Cipta.

Baidhawy, Zakiyuddin. 2005. Pendidikan Agama Berwawasan Multikultural. Jakarta: Penerbit Erlangga.

Depdiknas. 2008. Kamus Besar Bahasa Indonesia. Jakarta: PT. Gramedia Pustaka Utama. Furchan, Arif. 1992. Pengantar Metode Kualitatif. Surabaya: Usaha Nasional.

37. James A. Banks, Multicultural...... 
Hadi. 1986. Metode Research. Yogyakarta: Gajah Mada University Press.

Hamalik, Oemar. 2006. Proses Belajar Mengajar. Bandung: Bumi Aksara.

Hamdani. 2010. Strategi Belajar-Mengajar. Bandung: Pustaka Setia.

Hamka, Abdul Azis. 2011. Pendidikan Karakter Berpusat Pada Hati. Jakarta: AlMawardi Prima.

Jacobsen, David A., Paul Eggen, Donald Kauchak. 2009. Methods for Teaching. Yogyakarta: Pustaka Pelajar.

Majid, Abdul dan Dian Andayani. 2006. Pendidikan Agama Islam Berbasis Kompetensi. Bandung: Remaja Rosdakarya.

Mas'ud, Abdurrahman. 2003. Menggagas Format Pendidikan Nondikotomik. Yogyakarta: Gama Media.

Moleong, Lexy J. 2007. Metodologi Penelitian Kualitatif. Bandung: Remaja Rosdakarya.

Nasution. 1992. Metode Penelitian Naturalistik Kualitatif. Bandung: Tarsito.

Sugiyono. 2006. Metode Penelitian Kuantitatif \& Kualitatif. Bandung: Alfabeta.

Tafsir. 1992. Ilmu Pendidikan Perspektif Islam. Bandung: Remaja Rosda Karya. 